\title{
Post-operative pain management for single-level lumbar disc herniation surgery: A comparison of betamethasone, ibuprofen, and pregabalin
}

\author{
Tek seviyeli lomber disk herni cerrahisinde cerrahi sonrası ağrı yönetimi: Betametazon, \\ ibuprofen ve pregabalinin karşılaştırılması
}

(1) Emre BiLGiN, (1) Ali İhsan ÖKTEN

\begin{abstract}
Summary
Objectives: The aim of this study was to compare the effects of pregabalin, betamethasone, and ibuprofen on post-operative pain management in patients with single-level lumbar disc herniation surgery.

Methods: The present study was a randomized prospective study conducted at a tertiary university hospital. Sixty patients were equally divided into three groups based on whether they were treated with pregabalin (Group 1), ibuprofen (Group 2), and betamethasone (Group 3). Patients whose pre-operative back and leg pain was evaluated using a visual analog scale (VAS) and the Oswestry scale were administered $100 \mathrm{mg}$ tramadol hydrochloride during surgery. The treatment efficiency was compared by assessing post-operative VAS scores at $24 \mathrm{~h}, 1$ week, and 1 month after and Oswestry scale at 1 month after surgery. Results: The VAS scores for pre-operative and post-operative back pain did not show significant differences between the results at 1 week and 1 month in any group. There was no significant drug efficacy between post-operative week 1 and postoperative month 1, except for pregabalin; an early effect was less frequently observed in the pregabalin group than in the ibuprofen and betamethasone groups.

Conclusion: Although the three groups treated for single-level lumbar disc herniation received similar post-operative analgesia at the end of post-operative month 1, the decrease in VAS scores for back and leg pain was significant in the betamethasone group in the $1^{\text {st }}$ post-operative $24 \mathrm{~h}$ and post-operative month 1.
\end{abstract}

Keywords: Betamethason; ibuprofen; lumbar disc herniation; pain management; pregabalin.

\section{Özet}

Amaç: Tek seviyeli lomber disk hernilerinde cerrahi sonrası ağrı kontrolünde pregabalin, betametazon ve ibuprofenin etkinliklerini karşılaştırmak amaçlanmıştır.

Gereç ve Yöntem: Randomize prospektif çalışmada 60 hasta 20'şer kişilik üç gruba (1. grup pregabalin, 2. grup ibuprofen ve 3. grup betametazon) ayrıldı. Cerrahi öncesi bel-bacak ağrıları vizüel analog skala (VAS) ve Oswestry skaları ile değerlendirilen hastalara cerrahi sırasında 100 mili gram tramodol hidroklorür verildi. Cerrahiden sonra ilk 24 saat, 1. hafta ve 1. ay bel-bacak ağıı değerlendirmesi vizüel analog skalası ve 1.ayda Oswestry skalası tekrarlanarak, uygulanan ilaçların etkinlikleri kıyaslandı. Bulgular: Preoperatif ve postoperatif bel ağrısı değerlendirmede VAS değerlerinde tüm ilaç gruplarında 1. hafta ile 1. ay sonuçları arasında anlamlı bir fark bulunmamıştır. Bunun yanısıra bacak ağıısı vizüel analog skala değerlerinde bütün ilaç grupları zamana bağlı olarak azalış gösterirken, pregabalin dışında postop 1. hafta ve 1. ay düzeyleri arasında anlamlı bir fark saptanmamış, pregabalinin erken dönemde etkisi diğer iki ilaçdan daha az bulunmuştur. Postoperatif Oswestry düzeyleri ile preoperatif Oswestry değerleri karşılaştırıldığında tüm ilaç gruplarında anlamlı bir azalış gözlenmiştir.

Sonuç: Tek seviyeli lomber disk hernilerine uygulanan cerrahi sonrasında her üç grupta 1. ayın sonunda birbirine yakın postoperatif analjezi sağlansada; cerrahi sonrası ilk 24 saat ve 1 . ayda betametazonun bel-bacak ağrı değerlendirmesindeki vizüel analog skala değerlerindeki düşüş daha anlamlı bulunmuştur.

Anahtar sözcükler: Betametazon; ibuprofen; lomber disk hernisi; ağrı yönetimi; pregabalin.

Department of Neurosurgery, Adana City Training and Research Hospital, Adana, Turkey

Submitted (Başvuru tarihi) 16.05.2020 Accepted after revision (Düzeltme sonrası kabul tarihi) 02.09.2020 Available online date (Online yayımlanma tarihi) 11.01.2021

Correspondence: Dr. Emre Bilgin. Adana Şehir Eğitim ve Araşstrma Hastanesi, Beyin ve Sinir Cerrahi Kliniği, Adana, Turkey.

Phone: + 90 - 322 - 4559000 e-mail: dremreblgn@gmail.com

(- 2021 Turkish Society of Algology 


\section{Introduction}

The annual incidence of back pain in healthy adults varies between $10 \%$ and $15 \%$; the average visual analog scale (VAS) score is 4 . Intervertebral disc herniation, one of the most frequent causes of back and leg pain, generally results in a throbbing pain in the legs. ${ }^{[1]}$ Lumbar disc surgery is associated with moderateto-severe back and radicular pain. Most patients show symptomatic recovery from acute intervertebral disc herniation without surgical intervention. Surgical intervention is recommended in patients who have persistent symptoms, have neurological deficiencies, and do not experience pain relief with analgesics. Almost two-thirds of such patients recover completely following lumbar discectomy. However, because of inflammatory reactions in the dorsal root ganglia or sensorial nerve roots, pain may persist in the post-operative period. ${ }^{[1]}$ Inflammation and the control of post-inflammatory pain are among the most concerning post-operative complications.

Various nociceptive mechanisms underpin the pathophysiology of pain. Multimodal analgesic methods are necessary to ensure a reinforcing and synergistic effect. Despite recent developments in pain control and analgesic pharmacology, the effectiveness of post-operative pain control is still disputable. A recent study demonstrated that $54 \%$ of patients experienced moderate-to-severe postoperative pain post-discharge. ${ }^{[2]}$

The use of opioids, which are essential for post-operative pain management, is limited because of their adverse effects, for example, nausea, emesis, and sedation. Because of such adverse effects, multimodal analgesic methods are used as an alternative to opioids. Pregabalin is a multimodal analgesic. ${ }^{[3]}$ Pregabalin, which was originally classified as an anticonvulsant, adheres to presynaptic voltage-gated calcium channels and is used in the treatment of neuropathic pain. ${ }^{[4]}$

Various corticosteroids are used to decrease pain and can be administered by epidural or local irrigation, ${ }^{[5]}$ systematic approaches (intravenous [IV] and intramuscular $[\mathrm{IM}]){ }_{{ }^{[6,7]}}$ or intrathecal approaches. ${ }^{[8]}$ Among these, betamethasone is a steroid which has IM applications and a long half-life (36-54 h). Steroids, which have an average-to-long half-life, can be used to treat lumbar disc herniation. ${ }^{[9]}$
Nonsteroidal anti-inflammatory drugs (NSAIDs) are agents that have been used for many years in the managements of pain and inflammation. Ibuprofen is a NSAID that inhibits the conversion of arachidonic acid into prostaglandin and prevents pain receptors from becoming sensitive to injury. ${ }^{[10]}$ This drug, which is readily absorbed, exerts a systemic effect after attaining an adequate concentration in the blood. ${ }^{[11]}$

\section{Material and Methods}

The present study included 60 patients American Society of Anesthesiologist (physical status I or II) with single-level lumbar disc herniation who underwent surgery at our clinic between July 2018 and October 2018. The patients were randomly allocated to one of three groups. Necessary approval was obtained from the ethics committee (June 19, 2018; approval number, 201). The study participants comprised individuals aged 20-50 years who had single-level lumbar disc herniation. Disc pathology compatible with their clinic in lumbar magnetic resonance imaging and left (24 patients) and right (36 patients) radiculopathy findings in electromyography were found in the patients included in the study. Patients included in the study did not receive physical therapy before surgery and during the $1^{\text {st }}$ month after surgery. The time between the beginning of the patients' complaints and the surgery is a maximum of 1 week. Patients who fulfilled the following criteria were excluded; two or more lumbar disc herniations, previous instrumentation and fusion surgery, alcohol use, use of anti-epileptic drugs, spinal deformities, obesity (body mass index $>30$ ), chronic illness, failure to understand VAS and the Oswestry scale, known allergies to the study drugs, aged $<20$ years and $>50$ years, without radicular pain, and dural damage during surgery.

Patients were required to provide written informed consent subsequent to registration. The VAS (this scale consisted of an unmarked $10 \mathrm{~cm}$ line on which $0 \mathrm{~cm}$ representing no pain and $10 \mathrm{~cm}$ representing the worst pain imaginable) and Oswestry scale were explained to the patients before they evaluated and completed the form to assess the severity of their back and leg pain. The patients in Group 1 were administered $75 \mathrm{mg}$ pregabalin orally (tablet) twice on the $1^{\text {st }}$ day and were required to continue taking the drug until surgery at the end of the $1^{\text {st }}$ week. Following discharge, patients were asked to take $150 \mathrm{mg}$ 
pregabalin orally (tablet) twice a day and to stop taking it at the end of week 1. Patients in Group 2 were administered $400 \mathrm{mg}$ ibuprofen orally (tablet) twice a day before surgery and were asked to take only this drug for 1 week. Following surgery, patients in Group 2 were prescribed 400 mg ibuprofen orally (tablet) twice a day for 1 week. Patients in Group 3 were administered $2 \mathrm{mg} / \mathrm{ml}$ betamethasone for 1 week before surgery and underwent surgery at the end of this period. Patients in Group 3 were administered $1 \mathrm{ml}$ betamethasone through IM injection during surgery and were prescribed $1 \mathrm{ml} \mathrm{IM}$ betamethasone postoperatively before discharge.

All groups were administered $100 \mathrm{mg}$ tramadol hydrochloride IV after they had regained while they were asleep under general anesthesia. Patients were mobilized within $8 \mathrm{~h}$ after surgery. Patients were required to complete the VAS before discharge and 1 week post-discharge. One month after discharge, the patients were contacted by telephone and were required to reevaluate the severity of their back and leg pain by completing the VAS and Oswestry scale again.

\section{Surgical method}

All patients underwent surgery under intratracheal general anesthesia and in a prone position by adjusting the operation table to flexion. The surgical area was stained with povidone iodine. Median lumbosacral skin was passed subcutaneously at the level of the lumbar herniation, and the paraspinal muscles were dissected using sharp scalpels at the lumbar herniation site. The distance was controlled with scopy, and after the distance was determined, microsurgical hemipartial laminectomy was performed. The affected nerve root underwent foraminotomy, extruded or sequestered fragment excision (if any), and discectomy. After hemorrhage control, the operation table was readjusted to a flat position, and surgery was completed by suturing the flaps according to the anatomical location. Toward the end of surgery and before the patients regained consciousness, $100 \mathrm{mg}$ tramadol hydrochloride IV was administered.

\section{Statistical analysis}

Statistical analyses were performed using the Statistical Package for the Social Sciences version 15.0. First, the data were assessed for a normal distribu-
Table 1. The age ranges, age averages, and gender distributions of the groups

\begin{tabular}{lccc}
\hline Groups & Gender & Age range & $\begin{array}{c}\text { Average } \\
\text { of age }\end{array}$ \\
\hline $1^{\text {st }}$ group & $13 \mathrm{M} / 7 \mathrm{~F}(65-35 \%)$ & $26-49$ & 39.45 \\
$2^{\text {nd }}$ group & $13 \mathrm{M} / 7 \mathrm{~F}(65-35 \%)$ & $20-48$ & 37.45 \\
$3^{\text {rd }}$ group & $7 \mathrm{M} / 13 \mathrm{~F}(35-65 \%)$ & $22-49$ & 39 \\
All groups & $33 \mathrm{M} / 27 \mathrm{~F}(55-45 \%)$ & $20-49$ & 38.63 \\
\hline
\end{tabular}

M: Male; F: Female.

tion using the Kolmogorov-Smirnov test. Because the data did not conform to a normal distribution, statistical differences were determined using a Mann-Whitney U-test $(p<0.05)$. The lower letters, capital letters, and asterisks refer to pre-operative and post-operative differences between the drugs under the same conditions, differences among the groups with pre-operative and post-operative use of the same drug, and differences between the postoperative groups compared with the pre-operative groups, respectively. Changes are presented as percentages in parentheses.

\section{Results}

Sixty patients were enrolled in the study and were divided into three groups. Group 1 comprised 13 males (65\%) and 7 females (35\%), with an average age of 26-49 years (range, 39.45 years). Group 2 comprised 13 males (65\%) and 7 females (35\%), with an average age of 20-48 years (range, 37.45 years). Group 3 comprised 7 males (35\%) and 13 females (65\%), with an average age of 22-49 years (range, 39.54 years). In total, 33 patients were male $(55 \%)$ and 27 patients were female (45\%), with an average age of 20-49 years (range, 38.63 years) (Table 1 ).

In Group 1, 8 patients (40\%) had L5-S1 herniation, 8 (40\%) had L4-L5 herniation, and 4 (20\%) had L3-L4 herniation. In Group 2, 10 patients (50\%) had L5-S1 herniation, 9 (45\%) had L4-L5 herniation, and 1 (5\%) had L3-L4 herniation. In Group 3, 12 patients (60\%) had L5-S1 herniation, 7 (35\%) had L4-L5 herniation, and $1(5 \%)$ had L3-L4 herniation. In total, $30(50 \%)$ had L5-S1 herniation, 24 (40\%) had L4-L5 herniation, and 6 (10\%) had L3-L4 herniation.

Pre-operative back pain VAS scores showed a significant decrease during all post-operative processes in 
Table 2. Pre-operative and post-operative back pain VAS levels of the patients

\begin{tabular}{lcccc}
\hline Group & Preop VAS & Postop VAS-1 ${ }^{\text {st }}$ day & Postop VAS-1 st week & Postop VAS-1 st month \\
\hline 1 (Pregabalin) & $4.65 \pm 0.33^{\mathrm{a}} \mathrm{A}$ & $3.40 \pm 0.21^{\mathrm{a}} \mathrm{B}^{*}(27 \%)$ & $1.60 \pm 0.15^{\mathrm{a}} \mathrm{C}^{*}(44 \%)$ & $1.20 \pm 0.09^{\mathrm{a}} \mathrm{C}^{*}(48 \%)$ \\
2 (Ibuprofen) & $4.05 \pm 0.34^{\mathrm{a}} \mathrm{A}$ & $2.25 \pm 0.16^{\mathrm{b}} \mathrm{B}^{*}(66 \%)$ & $1.00 \pm 0.00^{\mathrm{b}} \mathrm{C}^{*}(75 \%)$ & $0.60 \pm 0.11^{\mathrm{b}} \mathrm{C}^{*}(80 \%)$ \\
3 (Betamethasone) & $6.00 \pm 0.39^{\mathrm{b}} \mathrm{A}$ & $3.15 \pm 0.17^{\mathrm{ac}} \mathrm{B}^{*}(74 \%)$ & $1.20 \pm 0.09^{\mathrm{ab}} \mathrm{C}^{*}(85 \%)$ & $0.95 \pm 0.09^{\mathrm{ab}} \mathrm{C}^{*}(84 \%)$ \\
\hline
\end{tabular}

VAS: Visual analog scale. Lower case letters $(a, b, c)$ indicate the significant differences among the different drugs at the same condition (preop or postop groups). Upper case letters (A, B, C) indicate the significant differences between the preop and postop durations treated with the same drug. Asterisks $\left({ }^{*}\right)$ represent the statistical differences in the postop groups when compared to the preop groups (changes were given as percentages in parenthesis) $(p<0.05)$.

Table 3. Pre-operative and post-operative leg pain VAS levels of the patients

\begin{tabular}{lcccc}
\hline Group & Preop VAS & Postop VAS-1 ${ }^{\text {st }}$ day & Postop VAS-1 ${ }^{\text {st }}$ week & Postop VAS-1 ${ }^{\text {st }}$ month \\
\hline 1 (Pregabalin) & $6.90 \pm 0.24^{\mathrm{a}} \mathrm{A}$ & $1.75 \pm 0.14^{\mathrm{a}} \mathrm{B}^{*}(75 \%)$ & $1.10 \pm 0.10^{\mathrm{a}} \mathrm{C}^{*}(84 \%)$ & $0.35 \pm 0.11^{\mathrm{a}} \mathrm{D}^{*}(90 \%)$ \\
2 (Ibuprofen) & $7.10 \pm 0.25^{\mathrm{ab}} \mathrm{A}$ & $1.10 \pm 0.10^{\mathrm{b}} \mathrm{B}^{*}(84 \%)$ & $0.90 \pm 0.07^{\mathrm{a}} \mathrm{B}^{*}(87 \%)$ & $0.80 \pm 0.09^{\mathrm{b}} \mathrm{B}^{*}(98 \%)$ \\
3 (Betamethasone) & $7.85 \pm 0.26^{\mathrm{bc}} \mathrm{A}$ & $0.75 \pm 0.14^{\mathrm{b}} \mathrm{B}^{*}(95 \%)$ & $0.20 \pm 0.09^{\mathrm{b}} \mathrm{C}^{*}(89 \%)$ & $0.15 \pm 0.08^{\mathrm{ac}} \mathrm{C}^{*}(98 \%)$ \\
\hline
\end{tabular}

VAS: Visual analog scale. Lower case letters $(a, b, c)$ indicate the significant differences among the different drugs at the same condition (preop or postop groups). Upper case letters (A, B, C, D) indicate the significant differences between the preop and postop durations treated with the same drug. Asterisks $\left(^{*}\right)$ represent the statistical differences in the postop groups when compared to the preop groups (changes were given as percentages in parenthesis) $(p<0.05)$.

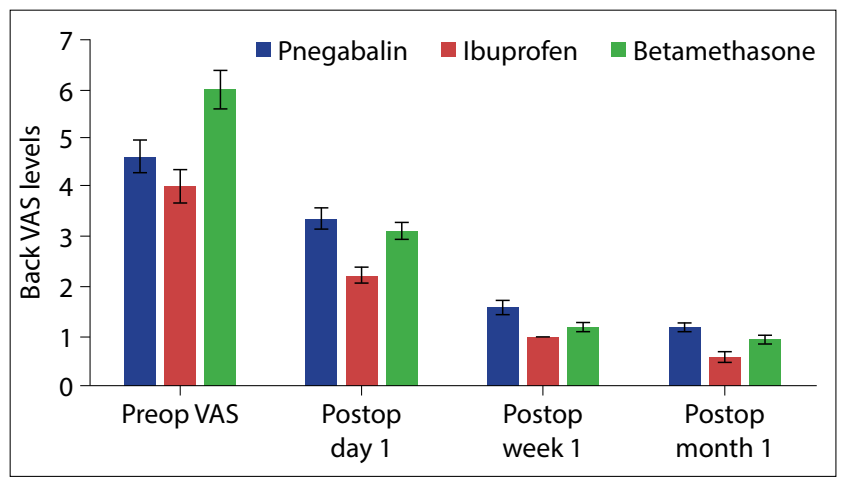

Figure 1.Pre-operative versus post-operative back pain VAS scores 1 day, 1 week, and 1 month after surgery.

VAS: Visual analog scale.

all groups. The lowest scores were observed in week 1 and month 1. Drug comparisons indicated that best result in betamethasone at the end of week 1 (85\%). Furthermore, none of the groups demonstrated a significant difference at the end of the week 1 or month 1 ( $p<0.05$; Table 2 and Fig. 1$)$.

Similar to the back pain results, a comparison of leg pain VAS scores demonstrated a significant decrease in VAS scores during the post-operative process in all three groups. All groups taking medicine amount decrease in time, and we observe that there were no differences observed between the VAS scores at week 1 and month 1, except in the pregabalin group. The best result of

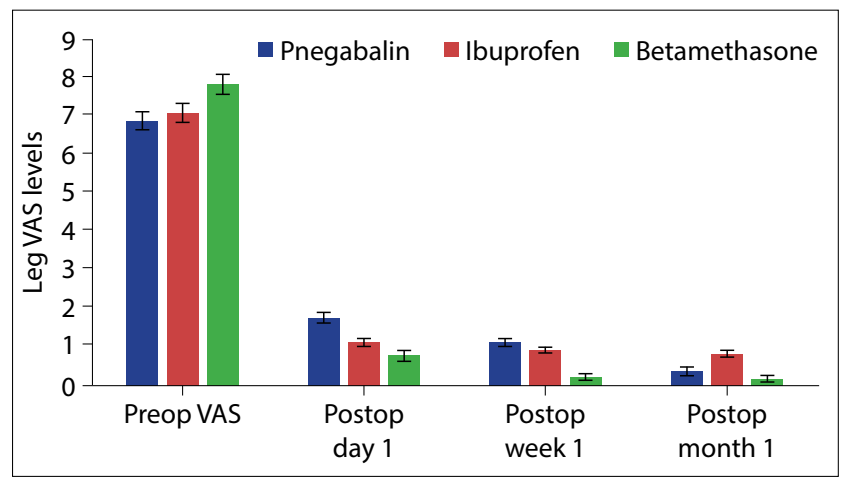

Figure 2. Pre-operative versus post-operative leg pain VAS scores 1 day, 1 week, and 1 month after surgery.

VAS: Visual analog scale.

measuring of VAS value with $98 \%$ was found in the groups administered post-operative ibuprofen and betamethasone at the end of month 1 $(p<0.05$; Table 3 and Fig. 2).

A comparison between the post-operative and preoperative Oswestry scale scores demonstrated that all groups showed a decrease, and the largest decrease about nearly $60 \%$ was observed in the betamethasone group (Table 4 and Fig. 3 ).

\section{Discussion}

The results of this study showed that betamethasone, pregabalin, and ibuprofen are effective for post-operative analgesia in lumbar disc herniation 
Table 4. Pre-operative and post-operative Oswestry rates of the patient groups

\begin{tabular}{lcc}
\hline Group & Preop OSW & Postop OSW-1 \\
\hline 1 (Pregabalin) month \\
2 (Ibuprofen) & $2.30 \pm 0.10$ (mild) & $1.05 \pm 0.05^{*}(\% 54)$ (no problem) \\
3 (Betamethasone) & $2.40 \pm 0.20$ (mild) & $1.00 \pm 0.0^{*}(\% 58)$ (no problem) \\
\hline
\end{tabular}

$0-20 \%=1$ (no problem); $20-40 \%=2$ (mild); $40-60 \%=3$ (progressive); $60-80 \%=4$ (complete). Asterisks $(*$ ) showed the statistical differences in the postop groups in contrast to the preop groups $(p<0.05)$.

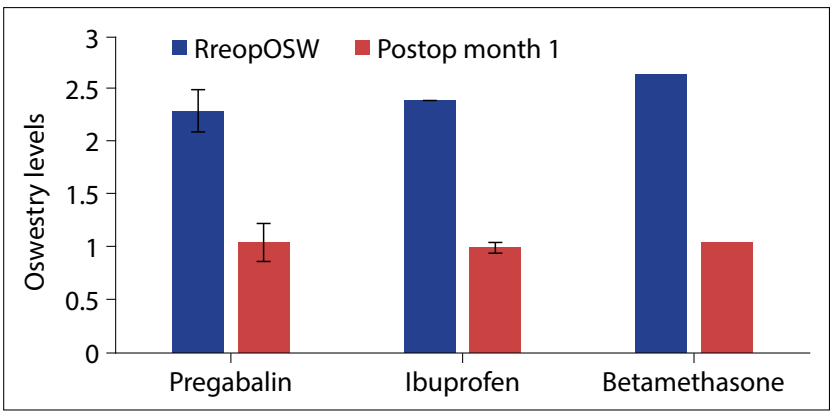

Figure 3. Pre-operative and post-operative (1 month) Oswestry scale scores.

surgery. Betamethasone and ibuprofen provide more efficient analgesia in the early period compared with pregabalin, while the analgesic effects of the three drugs are almost the same at the end of post-operative month 1 .

Lumbar disc herniation can cause back and leg pain, drop foot, and even cauda equina syndrome. The neural structure, which is subject to chronic compression by the nucleus pulposus, may undergo denaturation and present with edema. Inflammatory factors released by annulus fibrosus tears may stimulate nerve roots and regional tissues. Steroids can restrain inflammatory reactions by suppressing leukocyte adhesion, quinine and histamine release, and chemotaxis aggregation of inflammatory cells. Steroids have the capacity to inhibit prostaglandin synthesis; block C-fiber transmission, which stabilizes cell membranes; and decrease phospholipase-A2 activity. ${ }^{[12]}$ However, certain complications may occur, such as numbness and weakness due to nerve root irritation during surgery. ${ }^{[13]}$ Therefore, steroids have prominent effects in the treatment of lumbar disc herniation.

The systemic use of steroids helps to alleviate edema around nerve roots, relieve pain, and ensure easy mobilization as a result of their anti-inflammatory effects. ${ }^{[14]}$ Steroids are broadly used to treat acute se- vere discogenic pain. A previous study reported that VAS scores for leg pain in patients administered steroids decreased by $>20 \%$ in a single day and that steroids were effective for more than 30 days. ${ }^{[15]}$ Studies claim that epidural steroid injections can provide a small but distinctive decrease in VAS scores for leg pain between 2 and 6 weeks. ${ }^{[16]}$ In literature the results of previous studies that researching the effect of betamethasone in the treatment of severe leg pain are so close to the results of our study. Zhang et al. ${ }^{[17]}$ demonstrated that $1 \mathrm{ml}$ betamethasone applied epidurally following percutaneous endoscopic lumbar discectomy relieved back and leg pain in patients; these patients had a shorter return-to-work period. Steroids play a significant role in the early treatment of lumbar disc herniation;; ${ }^{[18]}$ however, inappropriate steroid use can lead to adverse effects such as spondylodiscitis and osteoporosis. ${ }^{[19]}$

In this study, pre-operative back and leg pain VAS scores in the betamethasone group decreased by $85 \%$ in post-operative week 1 and by $98 \%$ in postoperative month 1 . Similarly, Oswestry scale scores decreased in these patients by $60 \%$ at the end of month 1 when compared with pre-operative values; thus, betamethasone proved more effective than the other drugs.

NSAIDs can be administered at various doses over long periods to eliminate inflammation. They inhibit the conversion of arachidonic acid into prostaglandin and prevent sensitization of pain receptors. Ibuprofen inhibits cyclooxygenase and has anti-inflammatory and analgesic effects. Oral ibuprofen partially blocks the propagation of prostaglandins and helps suppress inflammation. Well-tolerated oral ibuprofen has analgesic, antipyretic, and anti-inflammatory effects. ${ }^{[20]}$

A meta-analysis by Zhang et al. ${ }^{[21]}$ revealed that NSAIDs are effective for pain management. They 
highlighted that NSAIDs decreased VAS scores in the first $12 \mathrm{~h}$ and were more reliable for pain management after lumbar vertebrae surgery compared with opioids. In the present study, the largest decrease in VAS scores in the first $24 \mathrm{~h}$ was observed in the betamethasone group, while the decrease in VAS scores over the same period in the ibuprofen group was in accordance with the literature.

The efficiency of NSAIDs for pain management has been proven. ${ }^{[22]}$ NSAIDs are more efficient and cause less nausea and emesis. The use of NSAIDs in proper doses alleviated opioid drug intake and their associated adverse effects. ${ }^{[23]}$

Similar to ibuprofen, NSAIDs can be used as multimodal analgesics in combination with opioids. In this study, all patients were administered $100 \mathrm{mg}$ tramadol hydrochloride IV during surgery and before patients regained consciousness.

Kelsaka et al. ${ }^{[24]}$ inferred that a single dose of IV NSAID (dexketoprofen) administered to patients undergoing microdiscectomy ensured post-operative analgesia in the first $8 \mathrm{~h}$. The present study observed similar results, although betamethasone surpassed the other drugs in providing the most efficient analgesia in the first 8 and $24 \mathrm{~h}$ and in its ability to decrease VAS scores.

Pregabalin, originally considered an anticonvulsant drug and used in the treatment of neuropathic pain, is recommended as a component of multimodal analgesia. ${ }^{[3,25]}$ It was demonstrated that low doses of pregabalin had an analgesic effect in the context of post-operative pain. ${ }^{[26]}$ Meta-analyses investigating gabapentinoids showed that they decreased post-operative pain and were beneficial if used after spinal surgery. ${ }^{[26,27]}$

Fujita et al. ${ }^{[28]}$ indicated that a single dose of pregabalin $(150 \mathrm{mg}$ ) reduced VAS scores in the post-operative $2 \mathrm{~h}$ following spinal surgery and the necessity for opioids was decreased up to $12 \mathrm{~h}$ postoperatively.

Many studies have specified that low single doses (150 or $300 \mathrm{mg}$ ) of pregabalin are efficient for postoperative analgesia and decrease the use of post-operative opioids. ${ }^{[29-31]}$ In the present study, the pregaba- lin group continued oral pregabalin treatment in the post-operative period. The decrease in back and leg pain VAS scores on post-operative day 1 and week 1 was lower than that in the other two groups, and the decrease in VAS scores was almost the same in the other two groups at the end of month 1.Thus, the findings of the present study were in accordance with those in the literature, and patients did not require post-operative opioids or any other additional analgesic drugs.

This study has some limitations: (1) Small number of patient with related to our study; (2) dimension of group studies make the research difficult; (3) scope of the study in time is shorter range; and (4) proximity of the researcher to the problem being studied is smaller amount so that we have limited sample.

In brief, the drugs administered to the patients led to a significant decrease in post-operative VAS scores and the patients were able to perform daily activities a short time after surgery. Three groups treated for single-level lumbar disc herniation received similar post-operative analgesia at the end of post-operative month 1, the decrease in VAS scores for back and leg pain was statistically significant in the betamethasone group in the first post-operative $24 \mathrm{~h}$ and post-operative month 1 . This study demonstrates that there is no need for patients to be administered a large number of drugs at high doses to achieve analgesia after surgery.

Ethics Committee Approval: The Adana City Training and Research Hospital Clinical Research Ethics Committee granted approval for this study (date: 19.06.2018, number: 201).

Conflict-of-interest issues regarding the authorship or article: None declared.

\section{Peer-rewiew: Externally peer-reviewed.}

\section{References}

1. Govind J. Lumbar radicular pain. Aust Fam Physician 2004;33(6):409-12.

2. Buvanendran A, Fiala J, Patel KA, Golden AD, Moric M, Kroin $J S$. The incidence and severity of postoperative pain following inpatient surgery. Pain Med 2015;16(12):2277-83.

3. Penprase B, Brunetto E, Dahmani E, Forthoffer JJ, Kapoor S. The efficacy of preemptive analgesia for postoperative pain control: A systematic review of the literature. AORN J 2015;101(1):94-105. [CrossRef]

4. Taylor CP. Mechanisms of analgesia by gabapentin and pregabalin--calcium channel alpha2-delta [Cavalpha2- 
delta] ligands. Pain 2009;142(1-2):13-6. [CrossRef]

5. Ng LC, Sell P. Outcomes of a prospective cohort study on peri-radicular infiltration for radicular pain in patients with lumbar disc herniation and spinal stenosis. Eur Spine J 2004;13(4):325-9. [CrossRef]

6. Karst M, Kegel T, Lukas A, Lüdemann W, Hussein S, Piepenbrock SEffect of celecoxib and dexamethasone on postoperative pain after lumbar disc surgery. Neurosurgery 2003;53(2):331-6. [CrossRef]

7. Lundin A, Magnuson A, Axelsson K, Kogler H, Samuelson $\mathrm{L}$. The effect of perioperative corticosteroids on the outcome of microscopic lumbar disc surgery. Eur Spine J 2003;12(6):625-30. [CrossRef]

8. Langmayr JJ, Obwegeser AA, Schwarz AB, Laimer I, Ulmer $\mathrm{H}$, Ortler M. Intrathecal steroids to reduce pain after lumbar disc surgery: A double-blind, placebo-controlled prospective study. Pain 1995;62(3):357-61. [CrossRef]

9. McCormick Z, Kennedy DJ, Garvan C, Rivers E, Temme K, Margolis $S$, et al. Comparison of pain score reduction using triamcinolone vs. betamethasone in transforaminal epidural steroid injections for lumbosacral radicular pain. Am J Phys Med Rehabil 2015;94(12):e122-4. [CrossRef]

10. Ciftci B, Ekinci M, Celik EC, Kaciroglu A, Karakaya MA, Demiraran $Y$, et al. Comparison of intravenous ıbuprofen and paracetamol for postoperative pain management after laparoscopic sleeve gastrectomy. A randomized controlled study. Obes Surg 2019;29(3):765-70. [CrossRef]

11. Sandborn WJ, Hanauer SB, Buch A. Comparative pharmacokinetics of equimolar doses of 5 -aminosalicylate administered as oral mesalamine (Asacol) and balsalazide: A randomized, single-dose, crossover study in healthy volunteers. Aliment Pharmacol Ther 2004;19(10):1089-98.

12. Lee JW, Kim SH, Lee IS, Choi JA, Choi JY, Hong SH, et al. Therapeutic effect and outcome predictors of sciatica treated using transforaminal epidural steroid injection. AJR Am J Roentgenol 2006;187(6):1427-31. [CrossRef]

13. Lee DY, Shim CS, Ahn Y, Choi YG, Kim HJ, Lee SH. Comparison of percutaneous endoscopic lumbar discectomy and open lumbar microdiscectomy for recurrent disc herniation. J Korean Neurosurg Soc 2009;46(6):515-21. [CrossRef]

14. Olmarker $K$, Holm $S$, Rosenqvist AL, Rydevik BJ. Experimental nerve root compression. A model of acute, graded compression of the porcine cauda equina and an analysis of neural and vascular anatomy. Spine 1991;16(1):61-9.

15. Finckh A, Zufferey $P$, Schurch MA, Balagué $F$, Waldburger $M$, So AK. Short-term efficacy of intravenous pulse glucocorticoids in acute discogenic sciatica. A randomized controlled trial. Spine (Phila Pa 1976) 2006;31(4):377-81.

16. Karppinen J, Malmivaara A, Kurunlahti M, Kyllönen E, Pienimäki T, Nieminen $\mathrm{P}$, et al. Periradicular infiltration for sciatica: A randomized controlled trial. Spine (Phila Pa 1976) 2001;26(9):1059-67. [CrossRef]

17. Zhang Y, Yang XJ, Zeng TH, Qiu YY, Wang YT, Liang FG. A Retrospective study of epidural and intravenous steroids after percutaneous endoscopic lumbar discectomy for large lumbar disc herniation. Chin J Traumatol 2017;20(1):34-8.

18. Wang H, Huang B, Zeng W, Li C, Zhang Z, Wang J, et al.
Comparison of early and late percutaneous endoscopic lumbar discectomy for lumbar disc herniation. Acta Neurochir (Wien) 2013;155(3):1931-6. [CrossRef]

19. Ahn Y, Lee SH. Postoperative spondylodiscitis following transforaminal percutaneous endoscopic lumbar discectomy: Clinical characteristics and preventive strategies. $\mathrm{Br}$ J Neurosurg 2012;26(4):482-6. [CrossRef]

20. Soutworth S, Peters J, Rock A, Pavliv L. A multicenter, randomized, double-blind, placebo-controlled trial of intravenous ibuprofen 400 and $800 \mathrm{mg}$ every 6 hours in the management of postoperative pain. Clin Ther 2009;31(9):1922-35. [CrossRef]

21. Zhang Z, Xu H, Zhang Y, Li W, Yang Y, Han T, et al. Nonsteroidal anti-inflammatory drugs for postoperative pain control after lumbar spine surgery: A meta-analysis of randomized controlled trials. J Clin Anesth 2017;43:84-9. [CrossRef]

22. Reuben SS, Buvanendran A, Kroin JS, Raghunathan K. The analgesic efficacy of celecoxib, pregabalin, and their combination for spinal fusion surgery. Anesth Analg 2006;103(5):1271-7. [CrossRef]

23. Kashefi P, Honarmand A, Safavi M. Effects of preemptive analgesia with celecoxib or acetaminophen on postoperative pain relief following lower extremity orthopedic surgery. Adv Biomed Res 2012;1:66. [CrossRef]

24. Kelsaka E, Güldoğus F, Çetinoğlu E. Effect of intravenous dexketoprofen use on postoperative analgesic consumption in patients with lumbar disc surgery. Agri 2014;26(2):82-6. [CrossRef]

25. Buvanendran A, Kroin JS. Multimodal analgesia for controlling acute postoperative pain. Curr Opin Anaesthesiol 2009;22(5):588-93. [CrossRef]

26. Zhang J, Ho KY, Wang Y. Efficacy of pregabalin in acute postoperative pain: A meta-analysis. $\mathrm{Br} J$ Anaesth 2011;106(4):454-62. [CrossRef]

27. Yu L, Ran B, Li M, Shi Z. Gabapentin and pregabalin in the management of postoperative pain after lumbar spinal surgery: A systematic review and meta-analysis. Spine (Phila Pa 1976) 2013;38(22):1947-52. [CrossRef]

28. Fujita N, Tobe M, Tsukamoto N, Saito S, Obata H. A randomized placebo-controlled study of preoperative pregabalin for postoperative analgesia in patients with spinal surgery. J Clin Anesth 2016;31:149-53. [CrossRef]

29. Ittichaikulthol W, Virankabutra T, Kunopart M, Khamhom W, Putarawuthichai P, Rungphet S. Effects of pregabalin on post operative morphine consumption and pain after abdominal hysterectomy with/without salphingo-oophorectomy: A randomized, double-blind trial. J Med Assoc Thai 2009;92(10):1318-23.

30. Kumar KP, Kulkarni DK, Gurajala I, Gopinath R. Pregabalin versus tramadol for postoperative pain management in patients undergoing lumbar laminectomy: A randomized, double-blinded, placebo-controlled study. J Pain Res 2013;24(6):471-8. [CrossRef]

31. Balaban F, Yağar S, Özgök A, Koç $M$, Güllapoğlu H. A randomized, placebo-controlled study of pregabalin for postoperative pain intensity after laparoscopic cholecystectomy. J Clin Anesth 2012;24(3):175-8. [CrossRef] 